PRACE NAUKOWE UNIWERSYTETU EKONOMICZNEGO WE WROCLAWIU

\title{
Malgorzata Dworakowska
}

Warsaw School of Economics

e-mail:mdwora@sgh.waw.pl

\section{FINANCIAL CONDITIONING \\ OF INVESTMENT ACTIVITY OF TERRITORIAL SELF-GOVERNMENT UNITS IN THE CHANGING ECONOMIC ENVIRONMENT}

\author{
UWARUNKOWANIA FINANSOWE \\ AKTYWNOŚCI INWESTYCYJNEJ \\ JEDNOSTEK SAMORZĄDU TERYTORIALNEGO \\ W ZMIENIAJĄCYM SIĘ OTOCZENIU GOSPODARCZYM
}

DOI: $10.15611 /$ pn.2017.476.08

Summary: An especially significant area in the activity of territorial self-government units is the execution of investment undertakings. However, it requires taking into account various factors influencing their launch and performance. Investment expenditure enables a reduction in differences as far as the development of territorial self-government units is concerned. The scale and range of investment activity pursued by territorial self-government units depend on the financial standing of these entities and it is budget analysis that serves the purpose of its examination. Finance is the key element of functioning of territorial self-government units and the basic marker of practicability and success of each investment. The article aims at presenting financial conditioning related to the budgetary situation of territorial selfgovernment units in Poland and their impact on the execution of investments by these entities. Thus, the parameters that were characterised were investment expenditure, own revenue, budgetary result and operating surplus in the years 2007-2015. The research procedure made use of non-reactive methods, namely the method of analysis of official documents and the historical and comparative method.

Keywords: territorial self-government units, investment activity, Poland.

Streszczenie: Szczególnie ważnym obszarem działania jednostek samorządu terytorialnego jest realizacja przedsięwzięć inwestycyjnych, ale wymaga ona uwzględnienia różnorodnych czynników mających wpływ na ich podejmowanie i prowadzenie. Wydatki na inwestycje pozwalają zmniejszyć różnice w rozwoju jednostek samorządu terytorialnego. Na skalę i zakres aktywności inwestycyjnej realizowanej przez jednostki samorządu terytorialnego oddziałuje stan finansów tych podmiotów, a jego badaniu służy analiza budżetu. Finanse są kluczowym elementem łączącym się z funkcjonowaniem jednostek samorządu terytorialnego i podstawowym wyznacznikiem realności i powodzenia każdej inwestycji. Celem artykułu jest przedstawienie uwarunkowań finansowych związanych z sytuacją budżetową jednostek 
samorządu terytorialnego w Polsce i ich wpływu na realizację inwestycji przez te podmioty. Charakterystyce poddano wydatki na inwestycje, dochody własne, wynik budżetów i nadwyżkę operacyjną w latach 2007-2015. W procedurze badawczej użyto metod badań niereaktywnych, wykorzystano metodę analizy dokumentów urzędowych i metodę historyczno-porównawczą.

Slowa kluczowe: jednostki samorządu terytorialnego, aktywność inwestycyjna, Polska.

\section{Introduction}

Territorial self-government units in Poland make important entities of the public sector and the economic environment in which they operate is a subject to dynamic changes. This environment also includes all the factors which externally affect the functioning of territorial self-government units. The space in which they perform their activities is influenced among others by economic, legal and political factors. What is observed in the economic space of territorial self-government units has an impact on their financial situation, determines the conditions in which they function and necessitates rapid responses to new challenges.

Not much research is devoted to the analysis of conditioning of investments undertaken in the public sector, including territorial self-government units, in the developing countries [cf. Clements et al. 2003]. The research result conducted so far reveal that these investments depend on a number of factors, in particular economic, financial, structural as well as political and institutional ones. Therefore, the analyses of the financial condition of territorial self-government units are indispensable as the fundamental element being the prerequisite for possible activity of these entities in all the areas.

Financial conditioning connected with the budgetary situation of territorial selfgovernment units plays the most important role in all the factors influencing launching and executing investments by the units. Finances are the key element related to their functioning and a basic determiner of the feasibility and success of each investment. The state of finances is on the one hand shaped by the amount of revenues and on the other by the orientation of the expenses. Revenues and expenditure of territorial selfgovernment units are varied as they stem among others from a different level of socio-economic development for particular parts of the country. Moreover, the relationship between the amount of revenues and the total expenditure should be taken into consideration as it is the source of information on the state of imbalance in budgets of territorial self-government units. Furthermore, the financial situation of territorial self-government units has an impact on the development of other areas of their functioning, provides information on the potential of economic development and enables comprehensive assessment of the activity of these entities [Wojciechowski 2012, p. 234-235]. 
Territorial self-government units incur expenditure on investments with a view to creating the municipal infrastructure which is to fulfil the residents' needs. The objective of municipal investments is mainly in construction, extension and modernisation of the widely understood technical and social infrastructure, which forms the basis of regular execution of own tasks as well as affects location and development decisions on the part of business entities [Jarosiński 2003, p. 35]. Infrastructure in territorial self-government units is encouragement to undertake and run business activity in the given area. Moreover, it indicates the structure of benefits offered to external entities and is the prerequisite for the existence of local entities, on many occasions creating one of the sources of competitive advantages for them [Borowski 2010, p. 32]. The volume of investments can be treated as an indicator of development and financial situation of the self-government unit and the present investment decisions affect the future of territorial self-government units.

The article aims at presenting financial conditioning related to the budgetary situation of territorial self-government units in Poland and their impact on the execution of investments by these entities. The characterised parameters included investment expenditure, own revenues, budgetary result and operating surplus in the years 2007-2015. Due to the limited scope of this study the statistical data were used, which were calculated for all the territorial self-government units without distinguishing their particular categories, that is gminas, cities with poviat rights, poviats and voivodships. The research procedure made use of non-reactive methods, namely the method of analysis of official documents and the historical and comparative method.

\section{Investment expenditure in the financial management of territorial self-government units}

Expenses incurred by territorial self-government units enable the fulfilment of collective needs of local and regional communities. The targets of budgetary expenses are dependent on expenditure priorities which are determined within the catalogue of public tasks assigned to be executed by territorial self-government units. These tasks may have various specific characteristics - among others tasks of investment nature and those going beyond investments are distinguished. The execution of budgetary expenses depends first and foremost on the amount of the obtained budget revenues.

Budgetary expenses of territorial self-government units are divided into current expenses and property expenses. Current expenses serve the purpose of financing the functioning of a self-government unit and they enable the maintenance and exploitation of the established infrastructure. Property expenses include investments and investment purchases, purchase and takeover of stocks and shares as well as contributions in commercial law companies [Ustawa z 27 sierpnia 2009, art. 236 ust. 4]. They are almost in full appropriated on investments of territorial self- 
government units. A substantial part of property expenses is investment expenditure. Its execution is of key importance for limiting the delayed development and subsequent investments in territorial self-government units which affect the country's attractiveness in terms of investments [Soszka-Ogrodnik 2014]. What poses a problem is the effect of forcing out investment expenditure by legally determined expenses.

It is easier to find in the budget and secure funds for investments if the budget has more money for disposal. When starting an infrastructural undertaking it has to be remembered that money must be secured for its completion and further exploitation. The execution of investments by territorial self-government units needs provision of stable sources of financing. Funds from foreign sources, especially the European Union may also be used for the accumulation of necessary amounts. So far they have diminished developmental inequalities among regions in Poland.

The data on the share of investment expenses in the total expenditure in territorial self-government units provides information what part of the budgetary expenses was allocated in activities classified as investments. Drawing on the share of investment expenses in the total expenditure ${ }^{1}$ in the years 2007-2015 (Table 1) it should be stressed that for all the units of territorial self-government the examined indicator had its lowest level in 2013 (18.2\%) and the highest in 2009 (24.8\%). The share of investment expenses in the total expenditure differs depending on the categories of self-government units - the smallest one can be found in poviats whereas the highest in voivodships, where these funds in particular serve the purpose of pursuing the policy of voivodship development.

Table 1. Share of investment expenses in the total expenditure in the years 2007-2015 (in \%)

\begin{tabular}{|c|c|c|c|c|c|c|c|c|c|}
\hline \multirow{2}{*}{\begin{tabular}{c} 
Specification \\
\cline { 2 - 10 }
\end{tabular}} & \multicolumn{8}{|c|}{ Year } \\
\cline { 2 - 10 } & 2007 & 2008 & 2009 & 2010 & 2011 & 2012 & 2013 & 2014 & 2015 \\
\hline Territorial self-government units & 20.3 & 21.2 & 24.8 & 24.3 & 22.7 & 19.1 & 18.2 & 20.3 & 18.9 \\
\hline
\end{tabular}

Source: own study based on [Sprawozdania Rady Ministrów...].

Differentiation in the share of investment expenses in the total expenditure results not only from the possibility of financing these outlays using available sources of obtaining funds but also from investment needs of particular units of territorial self-government. The required investment burden, enormous in some cases, is dependent on the revenue opportunities of units of territorial self-government, especially on the share of their own revenues in the total expenditure.

${ }^{1}$ Revenues, expenditure and budgetary result may be studied according to different approaches taking into account the following: planned amounts, planned amounts after changes and executed amounts. This article analyses executed amounts. 


\section{Own revenues in budgets of territorial self-government units}

Among budgetary revenues of territorial self-government units complementary revenues and own revenues are distinguished. Complementary revenues come in the form of general subvention and subsidies and they are a form of transfer of funds mainly from the state budget to budgets of territorial self-government units.

The notion of own revenues has not been defined anywhere and the Polish lawmaker characterised it by the determination of the types of budget proceeds under this category. Own revenues include revenues from taxes and charges, revenues from property, share in central taxes and other revenues. Own revenues should be the financial basis of the budget of each unit of territorial self-government, which means that their share in the structure of total revenues should be as high as possible as it has a beneficial impact on improvement in the financial background of these entities and in this way on the possibilities of execution of self-government investments.

With reference to the share of own revenues in the total revenues in the years 2007-2015 (Table 2) it can be seen that own revenues constituted at least half of the budget of all the units of territorial self-government in the years 2007-2008 and 2013-2015. In the other years complementary revenues outweighed own revenues. It must be underlined that own revenues of particular categories of territorial selfgovernment units are varied and the most favourable situation in this respect can be found in cities with poviat rights (the share of own revenues in the total revenues is at the average level of approximately $64 \%$ ) and in gminas. The situation in poviats is worrying though the share of own revenues in the total revenues is at the average level of approximately $30 \%$ and indicates that own revenues are not the basis of financial supplies. The considerable degree of dependence of territorial selfgovernment units on complementary revenues is visible, which does not concern only cities with poviat rights.

Table 2. The share of own revenues in the total revenues in the years 2007-2015 (in \%)

\begin{tabular}{|c|l|l|l|l|l|l|l|l|l|}
\hline \multirow{2}{*}{ Specification } & \multicolumn{7}{|c|}{ Year } \\
\cline { 2 - 10 } & 2007 & 2008 & 2009 & 2010 & 2011 & 2012 & 2013 & 2014 & 2015 \\
\hline Territorial self-government units & 56.4 & 55.0 & 48.6 & 48.3 & 48.8 & 49.1 & 50.0 & 50.7 & 52.0 \\
\hline
\end{tabular}

Source: own study based on [Sprawozdania Rady Ministrów...].

Among own revenues highly important is share in central taxes paid by citizens, which shows that the residents' incomes affect the level of the proceeds obtained by territorial self-government units. Thus, residents' affluence influences the financial situation of territorial self-government units. Any changes in terms of both wealth of the population for example in connection with the emergence of the economic crisis and the number of residents including first and foremost prevention of emigration as well as attracting population and private investors are perceptible in the budgetary situation of a unit of territorial self-government. 
Limitation on own revenues may be a result of consciously pursued too lenient tax policy on the part of the self-government decision makers, which exemplifies itself for instance by reducing rates of local taxes and lack of proper collection of taxes and local charges. Making use of reliefs in local taxes should be considered in at least two aspects. On the one hand, it may foster the increase in interest on the part of firms interested in running business operations and, on the other hand, through the creation of new workplaces the existing enterprises will contribute to the future improvement in the financial situation of a unit of territorial self-government. Higher share of own revenues in total revenues is beneficial as it enables the generation of higher percentage of funds, which to the greatest extent testifies financial selfsufficiency of a territorial self-government unit. The funds accumulated in such a manner are of substantial importance for the execution of expenditure, including investment expenses.

\section{Budgetary result of territorial self-government units}

When required, which usually entails the execution of investments, territorial selfgovernment units take advantage of revenues of returnable nature affecting budgetary results. It is typical of not only poorer but first and foremost richer units of territorial self-government, which are seriously involved in investment undertakings. If the budgetary result is negative, it denotes budget deficit whereas in the situation when it is positive - budgetary surplus. Each of these budget results consists of:

- the current result, that is the difference between current revenues and current expenses; current result may indicate the presence of operating surplus or deficit,

- the property result, that is the difference between property revenues and property expenses; property result indicates surplus or deficit in the property part.

The analysis of the issue of budgetary results needs reference to the principle of balancing budget in the current part, which has been in force for territorial selfgovernment units since 2011. According to the principle operating deficit is almost always prohibited. Presence of negative budgetary result is allowed only in the property part, whose specific characteristics are connected with the execution of investments and they have an impact on the development of territorial selfgovernment units.

Table 3 features data on the budgetary result with the division into the current and property results in the years 2007-2015. Positive budgetary result was observed for all the units of territorial self-government only in 2007 and 2015 whereas the other figures indicated negative budgetary result, whose greatest value occurred in 2010. In all the analysed cases the current result was positive and testified operating surplus while the property result was a negative figure and revealed deficit in the property part. Presence of the negative property result is strongly linked to investment expenditure. Thanks to the juxtaposition of the operating surplus and the total 
Table 3. Budgetary result in the years 2007-2015 (in mln PLN)

\begin{tabular}{|l|r|c|c|r|r|c|r|r|r|}
\hline \multirow{2}{*}{\multicolumn{1}{c|}{ Specification }} & \multicolumn{10}{|c|}{ Year } \\
\cline { 2 - 10 } & \multicolumn{1}{c|}{2007} & 2008 & \multicolumn{1}{c|}{2009} & \multicolumn{1}{c|}{2010} & \multicolumn{1}{c|}{2011} & \multicolumn{1}{c|}{2012} & \multicolumn{1}{c|}{2013} & \multicolumn{1}{c|}{2014} & \multicolumn{1}{c|}{2015} \\
\hline Total result, of which: & 2258 & -2602 & -12986 & -14970 & -10286 & -3046 & -380 & -2417 & 2604 \\
\hline current result & 17719 & 17739 & 11960 & 9284 & 10994 & 11626 & 14337 & 16318 & 18228 \\
\hline property result & -15461 & -20341 & -24946 & -24253 & -21279 & -14671 & -14717 & -18735 & -15624 \\
\hline
\end{tabular}

Source: own study based on [Nadwyżka operacyjna...].

negative result it can be shown how serious deficit in the property part, that is the one related to the execution of investments, territorial self-government units had.

Debt instruments of financing undertakings are used for widening permissible sources of investment capital in territorial self-government units. It should be assumed that if a choice of such ways of financing investments and the resulting structure of future years obligations do not cause negative consequences for the budget management of territorial self-government units and they contribute to faster achievement of planned tangible and quality effects, temporary negative budgetary results and their consequences may be treated as a normal phenomenon [Jarosiński 2013, p. 56]. Thus, the maintenance of high engagement in the execution of investments will be linked to the use of debt instruments of their financing and the resulting increase in the debt level related to high investment burden must be allowed. On many occasions it is debt instruments that enable accumulation of own contribution, necessary for territorial self-government units if they want to obtain nonreturnable financing from the Union funds and at the same time they are a tool of improvement in absorption capacity of these entities.

The analysis of the issue of budgetary results needs paying special attention to the issue of operating surplus. Its presence means that a territorial self-government unit is capable of executing subsequent investments or repaying earlier debts, which gives an indication of a good financial condition of self-government. Ability to generate operating surplus affects investment expenditure.

Table 4 presents detailed data concerning the number of territorial selfgovernment units with operating surplus and the operating deficit in the years 2007-

Table 4. Number of units of territorial self-government with operating surplus and operating deficit in the years 2007-2015

\begin{tabular}{|l|r|r|r|r|c|c|c|c|c|}
\hline \multirow{2}{*}{\multicolumn{1}{|c|}{ Specification }} & \multicolumn{8}{|c|}{ Year } \\
\cline { 2 - 11 } & 2007 & 2008 & 2009 & 2010 & 2011 & 2012 & 2013 & 2014 & 2015 \\
\hline with operating surplus & 2715 & 2721 & 2585 & 2336 & 2627 & 2707 & 2770 & 2754 & 2762 \\
\hline with operating deficit & 93 & 87 & 223 & 473 & 182 & 102 & 39 & 55 & 46 \\
\hline
\end{tabular}

Source: own study based on [Nadwyżka operacyjna ... ]. 
2015. The table proves a considerable increase in the number of territorial selfgovernment units with operating surplus in the period 2010-2013. Of all the units of territorial self-government the highest number of those with operating surplus was observed in 2013 when the number stood at 2770.

The increase in the number of territorial self-government units with operating surplus was affected among others by the implementation of the principle of balancing the budget in the current part. The activities undertaken in the recent years by an ever increasing group of territorial self-government units are easily noticeable. Their objective was to reach operating surplus and they also resulted from the activities of these entities with a view to meeting the valid debt limits. The presence of operating surplus positively influences the ability to incur new financial obligations, which, in particular, enables the execution of subsequent investments.

\section{Conclusion}

Despite substantial investment burden incurred in the recent years the needs of territorial self-government units are still visible in this respect. Investments are of significance both for residents and business entities and a unit of territorial selfgovernment, which executes this type of undertakings as well as its authorities. The execution of investments by territorial self-government units requires taking into consideration various factors influencing their launch and execution. The key role in this respect is played by financial conditioning related to the budgetary situation of territorial self-government units and it includes such values as: investment expenditure, own revenues, budgetary result and operating surplus. They are subject to the possibility of being shaped by a territorial self-government unit but they need taking into account changes occurring in the economic environment, in particular within the solutions specified in legal regulations. Therefore, this conditioning is at least in part independent of territorial self-government units.

The execution of investment expenditure enables reducing differences in the development of territorial self-government units. However, performance of these undertakings requires securing stable sources of financing. What should be remembered is the effect of forcing out investment expenditure by legally determined expenses. Engagement in investment undertakings required of territorial selfgovernment units is dependent on the revenue possibilities of these entities. Therefore, extremely important is the share of own revenues in the total revenues, whose increase is beneficial for the possibility of the execution of expenses, including those of investment nature. The share of own revenues in the total revenues should be as high as possible so that these funds will constitute the basis for financing for each unit of territorial self-government and thanks to this improve the possibilities of investment execution by these entities. Making use of debt sources of investment financing by territorial self-government units requires taking into consideration the issue of budgetary results, which is typical of these self-governments that are 
substantially involved in the execution of investments. It must be stated that the presence of deficit in the property part is allowed and it is strongly linked to investment expenditure. What is vital in the financial management of territorial selfgovernment units is the presence of operating surplus and the ability to generate it also affects investment expenditure and the ability to incur new obligations and it proves a good financial condition of the self-government. Higher operating surplus means greater opportunities of the execution of investments by a territorial selfgovernment unit.

\section{References}

Borowski P.F., 2010, Finansowanie infrastruktury w JST: przyczynek do dyskusji o rozwoju JST poprzez rozbudowę infrastruktury, Europejski Doradca Samorządowy, no. 4, pp. 32-37.

Clements B., Bhattacharya R., Nguyen T.Q., 2003, External debt, public investment, and growth in lowincome countries, IMF Working Paper, no. WP/03/249.

Jarosiński K., 2003, Finansowanie inwestycji komunalnych $w$ Polsce $w$ warunkach samorzadności lokalnej, OW SGH, Warszawa.

Jarosiński K., 2013, Finansowanie rozwoju lokalnego i regionalnego w warunkach deficytu budżetowego oraz dlugu publicznego, [in:] A. Alińska (ed.), Zwrotne instrumenty finansowe $w$ procesie stymulowania rozwoju regionalnego, OW SGH, Warszawa.

Nadwyżka operacyjna $w$ jednostkach samorzadu terytorialnego $w$ latach 2007-2015, Ministerstwo Finansów, Warszawa.

Soszka-Ogrodnik K., 2014, Polen verteidigt den ersten Platz im Standort-Ranking in der MOE-Region, http://www.ahk.pl (access 26.10.2016).

Sprawozdania Rady Ministrów z wykonania budżetu państwa w latach 2007-2015. Informacja o wykonaniu budżetów jednostek samorzadu terytorialnego, Rada Ministrów, Warszawa.

Ustawa z 27 sierpnia 2009 r. o finansach publicznych, tekst jedn. Dz. U. z 2016, poz. 1870 ze zm.

Wojciechowski E., 2012, Zarządzanie w samorządzie terytorialnym, Difin, Warszawa. 